\title{
The legal basis of students' rights and responsibilities in Turkish Education System*
}

\author{
Nihan DEMİRKASIMOĞLU *
}

\begin{abstract}
Students who are in the center of educational activities engage in a series of educational activity in educational organizations in order to carry out their learning experiences. During these activities, students have certain rights and responsibilities and a genuine position in the society. Therefore, it's important to have information about these responsibilities and rights for educators and students to be able to use these rights and obey the rules. In this paper, it is aimed at examining various aspects of legislation related to students in Elementary and Secondary Schools in Turkey. Within this frame first, the Constitution and the Ministry of National Education Legislation constitutes the main reference guides of this study. Within the purpose of this study, The Constitution, laws, international conventions and basically laws and regulations of Ministry of National Education were analyzed. As a result of this analysis, the most important deficiency is that the legislation related to student is very scattered. Although, it's possible to reach the rights and responsibilities of students among these laws and regulations, it will be better to gather their rights and responsibilities systematically.
\end{abstract}

Keywords: Student, educational legislation, right, responsibility.

* I would like to thank to Prof. Dr. Yasemin Karaman-Kepenekçi for her contribution with her comments in the development of this article.

** Res. Assist., Ankara University, Faculty of Educational Sciences, Department of Educational Administration and Policy, Ankara, Turkey. E-mail: nihansal.yahoo.com 


\section{SUMMARY}

Purpose and Significance: In this paper, it is aimed at examining various aspects of legislation related to students in Elementary and Secondary Schools in Turkey. Within this frame first, the Constitution and then Ministry of National Education Legislation constitutes the main reference guides of this study.

Students who are in the center of educational activities engage in a series of educational activity in educational organizations in order to carry out their learning experiences. During these activities, students have certain rights and responsibilities a genuine position in the society. Therefore, it's important to have information about these responsibilities and rights for educators and students to be able to use these rights and obey the rules.

Method: In the analysis, first the ideal form and then the present situation of the legislations was examined as far as possible under the aforementioned titles. Secondly, the legislations were analyzed with their positive and negative sides. Lastly, suggestions were made to contribute the present legislation to carry the ideal condition.

Results: National and International legislations related to student's right to education will be summarized as follows: Every child has the right to primary education as free and compulsory. The most important issue is that equality is essential to benefit from this right. All these legislations have a very important role especially for the girls who want to use this right but prevented by their parents. But it is not possible to say that eight-year primary education is ideal. Today, many countries effort to increase the compulsory education period. Increasing the period to 12 years like the countries such as Germany and Belgium will contribute to educate the human resource more effectively.

Every child is accepted to the nearest school since the compulsory education age and parents are responsible to apply for enrollment to school. Since 2007, e-school system has been introduced and all the educational process about a student is kept in this system including enrollment, student transfers, grades and psychological files. In e-school system, schools are bound to enroll the students to the nearest school with regard to their address.

In Elementary School Regulation, there is no limitation stated to the student attendence. At the other hand, it is stated that attendance is compulsory and essential in primary education. In this instance, the question of "how long attendance is essential?" remains vague. 
While disciplining the students, there is no doubt that the best way is to apply the sanctions least but to encourage them with rewards. However, sanctions will be effective in preventing undesired student behavior if it is well-proportioned. At this point, sanctions are necessary for enhancing discipline. Based on this idea, it is thought that disciplinary punishments taking place in elementary and secondary schools are proper if they are applied proportionally to the type of undesired behavior.

Students' health and security is the most important issue discussed here. Students' health and trust is the preliminary for the right of education. The terms related to this issue in legislations points that school administrators are charged with this duty. But in recent years, especially in secondary schools, when the increasing number of violence is considered, it can be said that current legislation is insufficient in solving the security problems. So, in secondary schools more effective legislations should be done in strengthening the weak points.

Discussion and Conclusion: As a result of this analysis, the most important deficiency is that the legislation related to student is very scattered. Although, it's possible to reach the rights and responsibilities of students among these laws and regulations, it will be better to gather systematically their rights and responsibilities. In the present situation, it's very difficult to pick up the necessary information for students and the other educational stakeholders among so many regulations. Perhaps the most practical way may be preparing student handbooks informing the educational stakeholders about these rights, responsibilities and duties like in United States of America. Such an arrangement will be very useful to present the necessary information in a well-organized form. 


\title{
Türk Eğitim Sistemi’nde Öğrencilerin Hak ve Sorumluluklarının Yasal Dayanakları*
}

\author{
Nihan DEMİRKASIMOĞLU**
}

ÖZ. Bu çalışmanın amacı, web tabanlı gerçekleştirilen Probleme Dayalı Öğrenme süreci sonunda öğrenci tutumlarını belirlemektir. Araştırmada tek grup sontest deneysel desen kullanılmıştır. Çalışma grubu, 2007-2008 öğretim yılı bahar yarıyılında, Yüzüncü Yıl Üniversitesi Eğitim Fakültesi İlköğretim Bölümü'nde öğrenim gören 30 birinci sınıf öğrencisinden oluşmaktadır. Çalışma grubu ögrencilerine 7 hafta boyunca Web Tabanlı Probleme Dayalı Öğrenme yaklaşımı ile ders işlenmiştir. Deneysel işlem sonunda Web Tabanlı Probleme Dayalı Öğrenme Tutum Ölçeği uygulanarak gerekli veriler elde edilmiştir. Öğrencilerin Web Tabanlı Probleme Dayalı Öğrenme sürecine ilişkin genel tutumları olumlu yönde yüksek çıkmıştır.

Anahtar Sözcükler: Probleme dayalı öğrenme, tutum, web tabanlı eğitim.

\footnotetext{
* Bu makalenin geliştirilmesinde eleştirileri ile katkıda bulunan Sayın Prof. Dr. Yasemin Karaman-Kepenekçi'ye teşekkür ederim.

** Arş. Gör., Ankara Üniversitesi, Eğitim Bilimleri Fakültesi, Eğitim Yönetimi ve Politikası Bölümü, Ankara, Türkiye. E-posta: nihansal.yahoo.com
} 


\section{GíRIS}

Öğrenciler, okulda yapılan bütün etkinliklerin ana merkezi olma özelliğini gösterirler. Çünkü eğitim etkinliklerinin odağında öğrencilere davranış kazandırma faaliyeti yer almaktadır. Okulda eğitim hizmetlerinin bu temel öğe etrafinda şekillendiği görülmektedir. (Cerit, 2003, 72). Balc1 (2005) öğrenciyi, "bir okulda eğitim programının gerektirdiği öğrenme yaşantılarının belli bir sürede kazandırıldığı kişi” olarak tanımlamıştır. Bilindiği üzere, okullar temelde öğrencinin eğitilmesi amaciyla kurulmuş eğitim kurumlarıdır. $\mathrm{Bu}$ kurumlarda verilen eğitim bir dizi etkinliğgi içermektedir. Bu etkinlikler süresince öğrencinin, toplumda kendine özgü bir konumu; yasalara göre ise, hakları ve sorumlulukları vardır. $\mathrm{Bu}$ nedenle öğrenci ile ilgili mevzuatın bilinmesi, öğrencilerin bu hak ve sorumluluklarını bilmesi ve kullanması; eğitimciler ve veliler için ise bu hakka sahip olanların haklarına uygun davranması bakımından büyük önem taşımaktadır.

\section{Eğitim Hakkı}

Eğitim, en değerli varlık olan insanın insan olabilme sürecidir. Eğitim, her şey insan için, onun mutluluğu için düşüncesinin gereğidir (Ataünal, 2003, 50). İnsanın en temel uğraşlarından birisi olan eğitim, insanın toplum içinde kendine etkili ve eylemli bir yer bulabilmesinin de önemli şartıdır. Tarihi süreç içerisinde, insanların birey olarak yaşayabilmeleri ve toplum dışı kalabilmelerinin mümkün olmayacağı görüşünden hareket eden insanlar bu yüzden de toplum kurallarına uymak ve bu kuralları uygulayabilmek için devlet düzenini oluşturmuşlardır (Balc1, 1996). Devlet ise tarihsel süreçte, toplumsal düzen kurallarını, bireylerin hak ve sorumluluklarını düzenlemiş ve bu düzenlemelere uyulmasını sağlamıştır. Zaman içerisinde sosyal devlet anlayışının gelişmesiyle devletin topluma sunmak zorunda olduğu en önemli görevlerden birisi de eğitim hakkı olmuştur.

Eğitim ve öğrenim hakkının tüm haklar içerisinde ayrı bir önemi ve rolü vardır. $\mathrm{Bu}$ hak, sahip olunan diğer hakların bilinmesinde, kullanılmasında, geliştirilmesinde ve korunmasında bir anahtar rolü oynamaktadır. Bu yüzden eğitim ve öğrenim hakkının çocuğun en önemli temel haklardan biri olduğu söylenebilir (Kepenekçi-Karaman, 2003, 189).

İşte bu nedenledir ki, başta öğrenciler olmak üzere tüm vatandaşların eğitim hakkı çeşitli ulusal ve uluslararası hukuk belgelerinde düzenlenmiştir. $\mathrm{Bu}$ düzenlemeler aşağıda sırasıyla öğrencilerin hak ve sorumluluklarının ulusal ve uluslararası yasal çerçevesi biçiminde incelenmiştir. 


\section{Öğrencilerin Eğitim Hakkının Ulusal Yasal Çerçevesi}

Türkiye'de eğitim hakk1, Anayasa'da temel hak olarak güvence altına alınmıştır. Eğitim ve öğretim hakkının kullanılması 222 sayılı İlköğretim ve Eğitim Kanunu ile 1739 sayılı Milli Eğitim Temel Kanunu'nda ayrıntılı olarak düzenlenmiştir.

1982 Anayasası'na Göre Eğitim Hakkı. Türkiye'de eğitim hakkı, 1982 Anayasas1 gereği devletin vatandaşlara sunmas1 gereken bir kamu hizmetidir. 1982 Anayasası'nın 10, 27. ve 42. maddeleri devlete, eğitim ve öğretim hakkını, özgürlüğünü ve eşitliğini sağlamaya yönelik önlemleri alma görevini yüklemiştir.

Anayasa'nın 10. maddesine göre, "Herkes, dil, ırk, renk, cinsiyet, siyasi düşünce, felsefi inanç, din, mezhep ve benzeri sebeplerle ayırım gözetilmeksizin kanun önünde eşittir", ve 27. maddesine göre "Herkes, bilim ve sanatı serbestçe öğrenme ve öğretme, açıklama, yayma ve bu alanlarda her türlü araştırma hakkına sahiptir”. Anayasa'nın 42. maddesine göre ise, "Kimse, eğitim ve öğrenim hakkından yoksun bırakılamaz. İlköğretim, kız ve erkek bütün vatandaşları için zorunludur ve devlet okullarında parasızdır. Devlet maddi olanaklardan yoksun başarılı öğrencilerin, öğrenimlerini sürdürebilmeleri amacı ile burslar ve başka yollarla gerekli yardımları yapar. Devlet, durumları sebebiyle özel eğitime ihtiyacı olanları topluma yararlı kılacak tedbirleri alır" ifadelerinden devletin tüm yurttaşlarına eğitim olanaklarını sağlamada birincil yükümlülüğe sahip olduğu anlaşılmaktadır.

İlköğretim ve Eğitim Kanunu'na Göre Eğitim Hakkı. İlköğretim ve Eğitim Kanunu'na göre ilköğretim, ilköğrenim kurumlarında verilir; öğrenim çağında bulunan kız ve erkek çocuklar için mecburi, devlet okullarında parasızdır. Mecburi ilköğretim çağı, 6-14 yaş grubundaki çocukları kapsar. Türk vatandaşı kız ve erkek çocuklar ilköğrenimlerini resmi veya özel Türk ilköğretim okullarında yapmakla mükelleftir (m.1-4). $\mathrm{O}$ halde, temel eğitim hizmetini devlet ne kadar mecburi eğitim çağındaki Türk vatandaşlarına sunmakla yükümlü ise, bu haktan yararlananlar da o oranda temel eğitim almaktan sorumludur. Dolayısıyla, temel eğitim söz konusu olduğunda vatandaş ve devlet arasında çift yönlü bir yükümlülükten söz edilebilir.

Kanunda 2003 yılında yapılan değişiklikle, önceki kanunun 12. maddesinde yer alan "ilköğretim okullarında eğitim zorunlu ve parasızıdır" ifadesi kaldırılmıştır. Yeni düzenlemede "eğitim zorunludur" ifadesine yer verilirken "parasızdır" ifadesine yer verilmemiştir. Oysa zorunlu ve parasız olması kanunda birlikte anılmalıdır.

Milli Eğitim Temel Kanunu'na Göre Eğitim Hakkı. 1739 sayılı Milli Eğitim Temel Kanunu Türkiye'de eğitim hakkını düzenleyen en önemli 
kanunlardan birisidir. Bu kanuna göre, temel eğitim dil, ırk, cinsiyet ve din ayrımı gözetilmeksizin herkese açıktır. Hiçbir aile, zümre ya da sınıfa imtiyaz tanınamaz (m.4). Eğitimde kadın, erkek herkese firsat ve imkan eşitliği sağlanır. Maddi olanaklardan yoksun başarılı öğrencilerin en yüksek eğitim kademelerine kadar öğrenim görmelerini sağlamak amaciyla parasız yatılı1ık, burs, kredi ve başka yollarla gerekli yardımlar yapılmaktadır. Özel eğitime ve korunmaya muhtaç çocukları yetiştirmek için özel tedbirler alınmaktadır (m.7). İlköğretim, 6-14 yaşlarındaki çocukların eğitim ve öğretimini kapsamaktadır. 1983 yılında 22. madde ile yapılan değişikliğe göre, ilköğretim, kız ve erkek bütün vatandaşlar için zorunludur ve devlet okullarında parasızdır. İlköğretimi tamamlayan ve ortaöğretime girmeye hak kazanmış olan her öğrenci, ortaöğretime devam etmek ve ortaöğretim olanaklarından ilgi, istidat ve kabiliyetleri ölçüsünde yararlanmak hakkına sahiptir (m.27). Bu kanunda geçen "temel eğitim” terimi "ilköğretim" olarak değiştirilmiş ve 1997 yılında yürürlüğe giren 4306 sayılı kanunla ayrı geçen "ilkokul" ve "ortaöğretim" ibareleri "ilköğretim okulu" olarak değiştirilmiş, sekiz y1llık kesintisiz eğitim zorunlu hale getirilmiştir.

Yukarıdaki yasal düzenlemelere bakıldığında, k1z erkek tüm öğrencilerin eğitim hakkından en azından temel eğitimden eşit ve parasız biçimde faydalanacağının öngörüldüğ̈̈ ve bu düzenlemelerin eğitim hakkını güvence altına alması bakımından ideal hukuk normlarına yaklaştığı söylenebilir.

\section{Öğrencilerin Eğitim Hakkının Uluslararası Yasal Çerçevesi}

Eğitim ve öğrenim hakkı, uluslararası hukuksal düzenlemelerde de güvence altına alınmıştır.

İnsan Hakları Evrensel Beyannamesi'nde Eğitim Hakkı. Türkiye, Birleşmiş Milletler tarafından 10 Aralık 1948 yılında yayınlanan "İnsan Hakları Evrensel Beyannamesi” ni 15 Aralık 1949 tarihinde imzalamıştır. Beyanname'nin eğitim hakkı ile ilgili hükümleri şöyledir (m.26): "Herkes eğitim hakkına sahiptir. Eğitim, en azından ilk ve temel eğitim aşamasında parasızdır. İlköğretim zorunludur. Teknik ve mesleksel eğitim herkese açıktır. Yükseköğretim, yeteneklerine göre herkese tam bir eşitlikle açı olmalıdır. Çocuklara verilecek eğitimin türünü seçmek, öncelikle ana ve babanın hakkıdır".

Çocuk Hakları Sözleşmesi’nde Eğitim Hakkı. Çocukların eğitim hakkını güvence altına alan düzenlemelerden en önemlilerinden birisi de “Çocuk Hakları Sözleşmesi”dir. Sözleşme, Birleşmiş Milletler Genel Kurulu tarafından 20 Kasım 1989 tarihinde kabul edilmiştir. Türkiye, Çocuk Hakları Sözleşmesi'ni 1990 yılında 43. ülke olarak imzalamıştır (KaramanKepenekçi, 2008). Sözleşmenin 28. maddesi eğitim ve öğretim hakkını 
tanımlamaktadır. Bu madde ile ilköğretimin herkes için zorunlu ve parasız hale getirilmesi, ortaöğretim sistemlerinin genel olduğu kadar mesleki nitelikte de olmak üzere çeşitli biçimlerde örgütlenmesini teşvik etmek ve bunların tüm çocuklara açık olmasını sağlamak, okullara düzenli biçimde devamın sağlanması ve okulu terk etme oranlarının düşürülmesi için önlem alma görevleri taraf devletlere yüklenmektedir. Taraf Devletler, annebabanın ve gerekiyorsa yasal vasilerin; çocuğun yeteneklerinin gelişmesiyle bağdaşır biçimde haklarının kullanılmasında çocuğa yol gösterme konusundaki hak ve ödevlerine, saygı gösterirler. Çocuğun düşünce, vicdan ve din özgürlükleri hakkına saygı gösterirler (m.14).

Ulusal ve uluslararası düzenlemeler çerçevesinde eğitim hakkının genel özellikleri şu şekilde betimlenebilir: Her çocuk, en azından temel eğitim düzeyinde parasız ve zorunlu eğitim hakkına sahiptir. Eğitimde bireylerin ve ailelerin inanç ve düşünceleri esas alınarak, çocuğa bu yönde eğitim verilmektedir. En önemlisi, eğitim hakkının kullanılmasında eşitlik esastır. $\mathrm{Bu}$ düzenlemelerin tümü, eğitim hakkından yararlanmak isteyen ancak veli tarafindan okula gönderilmeyen özellikle kız öğrencilerin en azından temel eğitim düzeyinde eğitim almasını sağlamakta önemli işleve sahiptir. Ancak bu haktan yararlanma süresinde devlet güvencesinin sadece temel eğitimle sınırlanmasının ideal hukuk normlarına uygun olduğu söylenemez. Dünya genelinde ülkeler, zorunlu eğitim süresinin artırılması yönünde çaba sarf etmektedir. Almanya, Belçika gibi ülkelerde 12 yıl olan temel eğitim süresinin Türkiye'de de ortaöğretimi kapsayacak biçimde genişletilmesi, yeni nesillerin bilgi ve beceri bakımından daha donanımlı yetiştirilmesini sonuç olarak da insan kaynağının geliştirilmesini sağlayacaktır.

\section{Çeșitli Değișkenler Açısından Öğrencilerle İlgili Mevzuat}

Öğrenci ile ilgili mevzuat; öğrencinin okula kaydı, öğrenci devamı, öğrencinin okulla ilişiğinin kesilmesi, öğrenci başarısının değerlendirilmesi, disiplin, öğrenci sağlığı ve güvenliği, öğrencinin yöneltilmesi ve rehberlik ile öğrencinin sosyal etkinliklere katılımı başlıkları altında incelenecektir.

\section{Öğrencinin Okula Kaydı}

Her çocuk, mecburi ilköğrenim çağına girdiği öğretim yılı başında ilköğretim okuluna kayıt ve kabul edilir. Her veli veya vasi veya aile başkanı, çocuğunu zamanında ilköğretim okuluna yazdırmakla yükümlüdür (İlköğretim ve Eğitim Kanunu, m. 46). MEB tarafından 2007 yılının Ocak ayında açılmış olan e-okul yönetim bilgi sistemi, öğrencinin okula kaydından itibaren, mezuniyetine kadar geçen tüm süreci içermektedir. Şu 
anda e-okul modülüne tüm resmi ve özel ilköğretim okulları, anaokulları ve özel eğitim okulları giriş yapmaktadır. Öğrencilerin okula kayıtları da, uygulanmakta olan bu e-okul sistemi ile elektronik ortamda gerçekleştirilmektedir. Bu çerçevede il ve ilçe milli eğitim müdürlüklerince kurulan Öğrenci Yerleştirme Komisyonu'nca, öğrencilerin oturdukları yere en yakın okula yerleştirilmeleri için kayıt alanları belirlendikten sonra ilgili okul müdürlüklerine duyurusu yapılmaktadır (Millî Eğitim Bakanlığı İlköğretim Kurumları Yönetmeliği, m.16).

E-okul sisteminde, esas olan öğrencinin en yakın okula kayıt edilmesi olduğundan, bu yeniliğin, velilerin çocuklarını gözde okullara torpille kaydettirmesini engelleme yönünde olumlu bir adım olduğu söylenebilir. Ayrıca gözde okulların yöneticilerinin, okula çok yakın oturan öğrenci velilerine kontenjanların dolu olduğunu ileri sürerek daha fazla kayıt ücreti veren ya da okula daha fazla katkı sağlayan öğrenci kayıtlarını kabul etmesinin önüne geçmek bakımından da olumlu bir gelişmedir. Bu sistem, özellikle çevrede başarı düzeyi yüksekokullara öğrencilerin kayıt edilmesinde, velilerden yüklü bağış ücretleri talep edilmesi ve okula yakın çevrede oturmadığı halde, gözde okullara kayıt yaptırılmasında hatır-gönül ilişkilerinin sonlandırılması bakımından da yerinde görünmektedir.

\section{Öğrenci Devamı}

Planlı öğretimde, öğretimin süresini oluşturan her dakikanın yeri ve önemi vardır. Bu süre içerisinde öğrencilerin kaçıracağı bir öğrenim görevi, onların gerçekleştirecekleri öğrenim yaşantılarının eksik kalmasına yol açar ve hedef davranışlara ulaşmalarını engeller. Her öğretim basamağında öğrenci devamsızlığı büyük bir sorundur. Devamsızlığı önlemek için verilen cezaların sınırlı bir etkisi vardır. Devamsız öğrenciyle, öğrencinin anababasıyla görüşmek, öğrencinin sorunlarının çözülmesine yardım etmek, toplumsal etkinlikler yaptırarak öğrenciye okulu sevdirmek, devamsızlığ 1 etkilemede etkili yollardır (Başaran, 2006, 363).

İlköğretim Kurumları Yönetmeliği’nde öğrencinin, derse özürsüz olarak girmemesi durumunda velisine ivedilikle bildirileceği ifade edilmektedir (m.26). Diğer yandan, ilköğretim kurumlarında okula devamın zorunlu olduğu da yer almaktadır. Ancak yönetmelikte devamsızlık için süre ile ilgili bir ölçüt bulunmamaktadır. Yönetmeliğin 27. maddesinde "İlköğretim kurumlarında okula devam esastır" hükmü, akla "Ne kadar süre ile devam esastır?" sorusunu getirmektedir ve bu konuda bir açıklama bulunmamaktadır. İlköğretim Kurumları Yönetmeliği’nden, öğrencinin sürekli devamsızlık yapması durumunda sınıf tekrarı yapmak durumunda 
olacağ 1 , ancak okula ara sira geliyorsa devamsızlıktan bırakılamayacağ sonucuna varılmaktadır.

Öğrencinin devamının esas olduğu hükmüyle çelişen bir diğer hüküm de şöyledir (m.21): "Yurt dişında bulunması, tutuklu olması, oturduğu yerde okul bulunmaması ve sağlik durumu nedeniyle okula devam edemeyenler ile 222 sayılı İlköğretim ve Eğitim Kanunu gereğince okula devamları sağlanan öğrencilerin başarı durumları belirlenirken, en az bir dönem puanı ve notu almış olmaları kaydıyla devam eden öğrenciler gibi işlem yapılır. Bu puan ve not, aynı zamanda yıl sonu puanı ve notu olarak değerlendirilir". Bu hükümden ise öğrencinin bir dönem puanı ya da notu almış olması durumunda ikinci dönem okula hiç gelmese dahi sınıf geçebileceği anlaşılmaktadır. Ayrıca, burada "devam eden öğrenciler" tanımlamasına örneğin, kaç iş günü devam eden öğrenciler olduğuna karar vermek mümkün değildir. Sonuç olarak, ilköğretim okullarında öğrencinin devamının esas ve zorunlu olması gereği, yine aynı yönetmelikte devam-devamsızlık ve sınıf geçmeyi değerlendiren hükümlerle açıkça çelişmektedir. Bu belirsizliğe ve bir bakıma keyfiyete son verilmesinde öğrencinin devamsızlık ölçütünün yönetmelikte açıkça belirtilmesi yerinde olacaktır.

Ortaöğretim kurumlarında ise, devam-devamsızlık durumu net bir biçimde açıklanmıştır. Öğrenciler, okula devam etmek zorundadır. Öğrencilerin devamsızlıkları hesaplanırken normal öğretim yapılan okullarda sabah ve öğleden sonraki süreler yarımşar gün, ikili öğretim yapılan okullarda bu süreler bir gün sayılır. Ders yılı içinde toplam 20 gün okula özürsüz olarak devam etmeyen öğrenciler, notları ne olursa olsun başarısız sayılır. Özürlü ve özürsüz devamsızlıklar ile okul yönetimince verilen izinlerin toplamı 45 günü aşamaz (Milli Eğitim Bakanlığ Ortaöğretim Kurumları Yönetmeliği, m.40). Bu hükümden anlaşılacağ 1 üzere, ortaöğretim kurumlarında öğrencinin başarı puanı kadar, okula devamı da önemlidir. Öğrenci çok başarılı bile olsa, özürlü ve özürsüz devamsızlıklar için belirtilen süreyi aştığında üst sınıfa geçememektedir. Bu yönüyle, yönetmeliğin öğrenci devamında yorum ya da belirsizliğe neden olmayacak ve keyfiyete olanak sağlamayacak biçimde düzenlendiği söylenebilir. Benzer ölçütlerin ilköğretim öğrencileri için de getirilmesi yerinde olacaktır.

\section{Öğrencinin Okulla İlişiğinin Kesilmesi}

Zorunlu öğrenim çağını bitirdiği öğretim yılı sonuna kadar ilköğretim okulunu bitiremeyen çocukların ilköğrenimlerini tamamlamak üzere en çok iki öğretim yılı daha okula devamlarına izin verilir (İlköğretim ve Eğitim Kanunu, m. 46). Ders yılı sonunda başarılı olanlara ilköğretim diploması 
düzenlenir. Başarısız olan sekizinci sınıf öğrencileri ile ara sınıflarda öğrenim çağı dışına çıkan ve iki yıl uzatma hakkını kullanan öğrencilerin, ders yılı sonunda öğrenim belgesi düzenlenerek okulla ilişkileri kesilir. $\mathrm{Bu}$ durumdaki öğrenciler Açık İlköğretim Okulu'na yönlendirilir (İlköğretim Kurumları Yönetmeliği, m.31). Bu hüküm herhangi bir nedenden dolay1 zorunlu eğitim çağı dışına çıkmış öğrencileri sistem dışına çıkarmak yerine, onlara temel eğitimi tamamlamasına olanak sağlaması ve öğrenimine devam etmesi için birden fazla hak vermesi dolayısıyla da öğrenciyi kazanmaya dönük olması bakımından yerindedir.

Ortaöğretim Kurumları Yönetmeliği’ne göre; özürleri nedeniyle okula devam edemeyen, okula devam ettikleri hâlde iki dönem notu alamayan öğrenciler ile ikinci dönem okula hiç devam etmeyen öğrenciler, o yıla ait öğrenim haklarını kullanmamış sayılır. Ancak öğrenim hakkının kullanılmamış sayılması hâli, orta öğretim süresince iki öğretim yılı ile sınırlıdır. Öğrenim süresi içinde ikinci defa sınıf tekrarı durumuna düşen öğrencilerin öğretim yılı sonunda okulla ilişiği kesilir. Mezun olamayan son sınıf öğrencilerinden sınıf tekrarı yapmış olanlar bir, sınıf tekrarı yapmamış olanlar ise iki öğretim yılı daha başarısız oldukları derslerden sorumluluk sınavına girebilir. Bu sınavlar sonunda da başarısız olan öğrencilerin öğretim yılı sonunda okulla ilişiği kesilir (m.57). Bu hükmün de, öğrenciye başarısızlık durumunda birden fazla hak tanıması nedeniyle öğrenci lehine düzenlenmiş olduğu söylenebilir.

\section{Öğrenci Başarısının Değerlendirilmesi}

Öğrencide gerçekleştirilmesi planlanan davranış değişikliklerinin ne derecede gerçekleştĭgi, eğitim çabalarının etkili olduğunu belirlemek için önemlidir. $\mathrm{Bu}$ nedenle programın hedeflerine ne derecede ulaşıldığııı belirlemek için değerlendirmeye gerek vardır (Tekin, 1991, 24). Bir eğitim programının başarıyla uygulanmasının ve yönetilmesinin göstergesi, öğrencilerin öğrenmedeki başarılarının derecesidir (Başaran, 2006, 366). Öğrenci başarısını değerlendirmede, ölçme ve değerlendirme uygulamaları açısından gerekli bilgi ve becerilere sahip olan öğretmenler, ölçme ve değerlendirme çalışmalarını sadece not vermek amacıyla yapılan bir iş olmaktan çıkarmışlar, öğrenmenin esas olduğu fikrinden hareketle, öğrenmeye katkı sağlayıcı bir araç niteliği kazandırmışlardır (Nartgün, 2003, 215).

İlköğretim öğrencilerinin değerlendirilmesi İlköğretim Kurumları Yönetmeliği'nde şöyle ifade edilmektedir (m. 47):

"Illköğretimde öğrenci, kendi yaş grubu içinde bir bütün olarak yetiştirilir ve değerlendirilir. İlköğretim, öğrencilerinin derslerdeki 
başarısızlığına bakılarak elenecekleri bir dönem değil, programda öngörülen derslerin ve sosyal etkinlik çalışmalarının ortak katkısıyla ilgi ve yeteneği ölçüsünde yetiştirilecekleri bir dönem olarak değerlendirilir. Öğrencinin yıllık başarısı, her dersten ayrı ayrı değil, tüm derslerde ve sosyal etkinlik çalışmalarındaki durumu, sınavlar, projeler, performans görevleri, ders içi performans ve Türkçe'yi doğru, güzel ve etkili kullanma becerisi ile öğrencilere kazandırılması hedeflenen tüm davranışlardaki etik değerleri benimsemesi de dikkate alınarak, bir bütün olarak değerlendirilir. Başarılı öğrenciler doğrudan bir üst sınıfa geçirilir."

$\mathrm{Bu}$ hüküm, öğrenciyi bir bütün olarak ele alması ve onu çeşitli yönleriyle geliştirmeyi esas alması yönüyle ideale yakındır. Başarı değerlendirmenin öğrenciyi başarısızlığı nedeniyle eleyebilecek bir araç olarak görülmemesi, onları ilgi ve yeteneği doğrultusunda yetiştirmenin esas olması ayrıca olumlu bir noktadır.

İlköğretim Kurumları Yönetmeliği’ne göre, yapılan ölçme ve değerlendirmeler sonucunda sinıf düzeyine göre yetersizlikleri görülen öğrenciler, sınıf ve branş öğretmenleri, okul rehber öğretmeni, okul yönetimi ve velinin kararlaştıracakları ve uygulayacakları önlemlerle ders yılı içinde özel olarak yetiştirilir. Kararlaştırılan önlemler, uygulamalar ve sonuçları tutanakla tespit edilir. Alınan bütün önlemlere rağmen bir üst sınıfta güçlüklerle karşılaşabilecek öğrencilerin sınıf geçmelerine veya bulundukları sınıfa bir yıl daha devam etmelerine; okul müdürünün veya görevlendireceği yardımcısının başkanlığında; sınıf öğretmeni, varsa okul rehberlik ve psikolojik danışma servisi ile branş öğretmenleri veya şube öğretmenler kurulu tarafından karar verilir. Alınan gerekçeli karar tutanakla tespit edilir ve sınıf geçme defterine işlenir. Tutanağın bir örneği öğrenci dosyasına konur, bir örneği de karar defterine yapıştırılır ve veli de bilgilendirilir (m.47). Bu madde, başarısı yeterli düzeyde olmayan öğrencilerin kurul kararıyla bir üst sınıfa geçirebileceğini ifade etmektedir. Öğrencinin sınıf tekrarı yapmasının, başarısız olarak damgalanmasının önüne geçmesi ve öğrencinin eğitim maliyetini azaltması bakımından olumlu değerlendirilebilir. Diğer yandan, öğrencinin bir üst sınıfa geçecek yeterliği olmamasına karşıllk öğrencinin beklenen yeterliliği olduğunu varsaymak bir üst sınıfta eksikliklerinin derinleşmesine ve sınıfın genel başarı düzeyine uyum sağlayamamasına neden olmaktadır. Bu noktada da, yönetmelikte yetersizliği olan öğrencilerin üst sınıfa geçirildikten sonra üst sınıfta öğrenim gören öğrencilerle arasındaki farkın kapatılmasına yönelik tedbirlerin alınmasına için gerekli düzenlemeler yapılması daha doğru olacaktır.

Yine aynı Yönetmeliğe göre, öğrencilerin başarısı; sınavlar, varsa proje ve öğrencilerin performanslarını belirlemeye yönelik çalışmalardan alınan puanlara göre tespit edilir. Öğrencilerin ders, uygulama ve değerlendirme 
etkinliklerine katılmaları zorunludur. Öğrencilerin performansını belirlemeye yönelik çalışmalar; ders ve etkinliklere katılım ile öğretmen rehberliğinde yapılan performans görevlerinden oluşur. Kaynaştırma yoluyla eğitim-öğretimlerine devam eden öğrenciler için bireyselleştirilmiş eğitim programı geliştirme birimi tarafından Bireyselleştirilmiş Eğitim Programı hazırlanır. Bu öğrenciler, programında yer alan amaçlara göre değerlendirilir (m.32). Bu düzenleme ile ödev yerine "performans görevi" getirilmiş, daha önceki yönetmelikte bunların ders dışında yapılması öngörülürken, son düzenlemeyle sınıf içinde öğretmen rehberliğinde yapılması hükmü getirilmiştir. Böylelikle, performans ödevlerini öğrencilerin yerine velilerin yapması konusunda veliler ve öğretmenler tarafından gelen şikayetlerin önüne geçilebilecektir.

İlköğretim Kurumları Yönetmeliği’ne göre (m.36):

"Sınav zamanı, en az bir hafta önceden öğrencilere duyurulur. Bir sınıfta/şubede bir günde yapılacak sınav sayısı ikiyi geçemez. Sınavların süresi bir ders saatini aşamaz. Derslerin özelliğine göre; klasik (essay) sınav türünde soru sayısının üçten az olmaması; çoktan seçmeli, eşleştirmeli, kısa cevaplı, açı uçlu, doğru/yanlış, tamamlamalı ve benzeri sınav türlerinde soru sayısının çok ve soruların kısa cevaplı olması, soruların konulara göre dağılımı yapılırken ağırlık bir önceki sınavdan sonra işlenen konulardan olmak kaydıyla geriye doğru azalan bir oranda ve dönem başından beri işlenen konulardan seçilmesi esastır. Sınavlardan önce sorularla birlikte cevap anahtarı da hazırlanır ve sınav kağıtları ile birlikte saklanır. Cevap anahtarında her soruya verilecek puan, ayrıntılı olarak belirtilir."

Eğer yukarıda, klasik sınavların ayrıntılı açıklanmasına gereksinim varsa, bu açıklamanın İngilizce bir kelime ile yapılmaması gerekir. Ayrıca bilineni (klasik) daha az bilinen "essay" kavramı ile açıklamak hiç anlamlı değildir. Başka bir nokta ise "essay", İngilizce'de "makale, deneme, yazı, kompozisyon" gibi anlamlara karşılık gelmektedir. Burada klasik sınavla kastedilen öyle görünüyor ki, açık uçlu sorulardan oluşan yazılı sınavlardır.

Ortaöğretim Kurumları Yönetmeliği'ne göre, ortaöğretim kurumlarında öğrenci başarısı, öğretim programı esas alınarak dersin özelliğine göre yazılı, sözlü ve uygulamalı sınav, ödev ve projeler ile işletmelerde beceri eğitimi, ders içi ve ders dişı eğitim-öğretim faaliyetleri değerlendirilerek tespit edilir. Öğretmen, söz konusu faaliyetlerle öğrencinin programlarda amaçlanan bilgi ve becerileri kazanıp kazanmadığını sürekli olarak kontrol ederek değerlendirir (m.17).

Ortaöğretim kurumlarında öğrenci başarısının değerlendirilmesinde uyulacak esaslar; sınav sayısı, sınav süresi, soru sayısı, soru türleri, sınavın içeriği, sınav tarihinin öğrencilere duyurulması gibi konular ayrıntılarıyla net 
bir biçimde açıklanmıştır (m.18). Bu yönleriyle başarı değerlendirmenin ölçütlerinin ideal biçimde düzenlendiğini söylemek mümkündür.

Ortaöğretim kurumlarında bir okulda aynı programı uygulayan öğretmenlerin ortak değerlendirme yapabilmelerine imkân vermek üzere her dönemde yazılı sınavların en az biri birlikte düzenlenir. Ortak sinavlar, zümre öğretmenler kurulunca belirlenecek tarihlerde o dersi okutan zümre ögretmenlerince ortak sorular ve cevap anahtarları hazırlanarak yapılır. Öğretmen tarafindan verilen puanlarla okul, bölge, il/ilçe çapında yapılan sınavlarda alınan puanlar arasında dikkat çekici ve anlamlı bir farklılık varsa ilgili yönetim birimlerince gerekli tedbirler alınır (m.21). Bu madde, aynı dersi okutan farklı öğretmenler ve onların sınıfları arasındaki farklılıkların gözlenebilmesi, okullar arası aynı programı izleyen öğrencilerin düzeyleri arasındaki farklılıkları ortaya çıkarılması ve öğretmenlere değerlendirmeleri hakkında karşılaştırma yapma olanağı sağlaması bakımından önemli ve güzeldir.

Ortaöğretim Kurumları Yönetmeliği'nde 2008 y1lında yapılan değişikliğe göre, "Doğrudan veya yıl sonu başarı notu ile sınıfını geçemeyen öğrencilerden; 9 uncu sinıfta en fazla 3, 10 uncu ve 11 inci siniflarda ise en fazla iki dersten başarısız olanlar sorumlu olarak bir üst sınıfa devam ederler. Ancak, alt sinıflar da dâhil toplam beşten fazla sorumlu dersi bulunanlar başarısız sayılır. Alan değişikliğinden dolayı sorumlu olunan dersler bu sayıya dâhil edilmez (m.34). Bu maddeye göre, önceki düzenlemede en fazla iki dersten başarısız olan öğrenci üst sınıfa sorumlu olarak geçebilirken, yeni düzenlemede 10 ve 11 . sınıflarda başarısız dersi toplam beş dersten sorumlu olarak geçebilmektedir. Bu madde, zaten eğitim kalitesi düşük olan liselerin kalitesini daha fazla düşürecek ve öğrenciyi korumaktan çok, öğrenciden beklenen standartların dolayısıyla da öğrenci niteliğinin düşmesine neden olacaktır. Kaldı ki, ortaöğretim kurumları zorunlu değildir ve ilköğretim kurumlarında öğrenciler ilgi ve yeteneklerine göre bir üst öğrenime yönlendirilirler. $\mathrm{Bu}$ hükmün uygulamaya yansıması, öğrenciye ilişkin akademik beklentinin ve başarı ölçütlerinin düşürülmesi biçiminde olacaktır. Böyle bir uygulama ise "kaliteden beklentisinden yoksun" bir anlayış izlenimi vermektedir.

\section{Öğrenci Disiplini}

Okulun öğrenci disiplini ile ilgili görevi öğrenciye hangi davranışların istenilir olduğunu öğretmek, öğrencilerin bu davranışları gösterme durumlarını izlemektir. Öğrenciye disiplin cezasının verilmesinin temel amacı istenmeyen davranışlar için caydırıcı ve yasaklayıcı etkisinden yararlanmak, aynı ve benzeri suç sayılan eylemlerin yenilenmesini önlemek, 
kurallara aykırı davranışlar karşısında uygulanacak yaptırımlar hakkında öğrencilere somut örnekler göstermektir. Disiplin, beklenen davranıştan daha iyi davranışta bulunanların ödüllendirilmesini, kötü davranışta bulunanların ise cezalandırılmasını kapsamaktadır (Taymaz, 2003, 192).

Okuldaki disiplinin kuralları şu özellikleri taşımalıdır (Başaran, 2006: 368):

1) Disiplin kuralları, her öğrencinin anlayacağı biçimde açık seçik yazilmalıdır.

2) Disiplin kurallarının uygulanmasında kararlı davranılmalıdır. Belli bir davranışa bir gün uygulanan, öbür gün uygulanmayan kurallar öğrencileri şaşırtır.

3) Davranışların alışkanlığa dönüşmesi için disiplin kuralları ölçütlerinin, yalnız okul içinde değil, elverdiğince okul dışında da uygulanması izlenmelidir.

İlk ve ortaöğretim kurumlarında öğrenci disiplini ile ilgili hususlar, "İlköğretim Kurumları Yönetmeliği” ile "Milli Eğitim Bakanlığı Ortaöğretim Kurumları Ödül ve Disiplin Yönetmeliği" ile düzenlenmiştir. İlköğretim Kurumları Yönetmeliği’nde disiplinle ilgili maddeler; "Öğrencilerin Olumsuz Davranışları ve Yaptırımlar" ile "Ö̉düllendirilecek Davranışlar ve Ödüller" başlıkları altında ifade edilirken, ortaöğretim öğrencileri ile ilgili düzenlemenin "Ödül ve Disiplin" başlığ 1 ile ifade edilmektedir. İlk olarak, disiplinin, ceza ile eş anlamlı tutulması yanlıştır. Çünkü disiplin, ceza ve ödülü kapsayan bir kavramdır (Kepenekçi-Karaman, 1997). Yukarıda da ifade edildiği gibi, disiplin yalnızca kurallardan sapan öğrencileri cezalandırmak için değil, aynı zamanda olumlu davranışları da pekiştirmek için kurulan bir düzen olarak görülmelidir. Bu nedenle söz konusu yönetmelikte, yaptırım, ödül ve cezayı kapsayan şemsiye bir kavram olarak düşünülmeli ve "Öğrenci Davranışları ve Yaptırımlar" gibi bir başlıkla yeniden düzenlenmelidir. Böyle bir ifade, öğrencinin davranışı olumlu ise ödüllendirmeyi, öğrencinin davranışı olumsuz ise bu davranışa uygun olan yaptırımı uygulamayı kapsayacaktır.

İlk ve ortaöğretim kurumlarında, tüm derslerin ağırlıklı not ortalamaları yönetmelikte belirlenen puanların üstünde olan öğrenciler "teşekkür", "takdir" ya da "üstün başarı" belgeleri ile ödüllendirilirler. Öğrencilerin olumlu davranış ve çalışmalarının ödüllendirilmesine ilişkin bu hükümler, öğrencilerin istenen davranışını benimsemesi ve pekiştirmesi bakımından teşvik edici ve olumludur.

İlköğretim okulu 6,7 ve 8 inci sınıf öğrencilerine; gelişim özellikleri dışındaki olumsuz davranışlarının özelliğine göre uyarma, kınama ve okul değiştirme yaptırımlarından biri uygulanır (İlköğretim Kurumları Yönetmeliği, m.108). O halde, öğrenci davranış1 için yaptırımlar, davranışın niteliğine göre hafiften daha ağıra doğru derecelendirilmiştir. Burada esas 
olan cezanın suça denk olmasıdır, çünkü gereğinden fazla ya da az verilen ilaç hastayı iyileştirmez (Başaran, 2006).

Öğrenci disiplinini sağlamada istenen şüphesiz ödülle öğrenciyi teşvik etmek ve yaptırımlara en az başvurmaktır. Ancak istenmeyen davranışların önlenmesinde yaptırımlar orantılı uygulandığında istenmeyen davranışın tekrarlanmasını engellemede etkili olabilir. $\mathrm{Bu}$ noktada yaptırımlara da disiplin sağlamada gereksinim duyulmaktadır. $\mathrm{Bu}$ yönüyle, disiplin cezalarının davranışın niteliğine orantılı uygulanması kaydıyla yerinde düzenlemeler olduğu düşünülmektedir.

\section{Öğrenci Sağlı̆̆g ve Güvenliği}

Öğrencilerin sağlığını korumak için gereken tüm işleri yapmak okul yönetiminin görevidir. Bu kapsamda; hastalık ve kazalara karşı tedbirler almak, öğrencilerin sağlığını tanımak, sağlık eğitimini gerçekleştirmek de okul yönetiminin görevidir. Okulun ve çevrenin temizliği, dersliklerin 1sınması, temiz içme suyunun sağlanması, salgın ve mevsimlik hastalıklara karşı hazırlıkların yapılması, beslenme için ayrılan yerlerin temizliği gibi sağlığın korunması ile görevler yerine getirilmelidir. Sağlık gibi, okul binasında can ve mal güvenliğinin sağlanması görevinden birince derecede sorumlu birim okul yönetimidir (Başaran, 2006, 372-447).

Öğrenci sağlığ1 ve güvenliği ile ilgili güvenliğin sağlanması ile ilgili İlköğretim Kurumları Yönetmeliği’nde şöyle bir hükme yer verilmiştir (m.139):

a) Öğrencilere okul ve çevresinde sağlıklı, güvenli bir eğitim-öğretim ortamı sağlanması esastır.

b) Okulun temizlik ve düzeninin sağlanması, derslik, laboratuvar, işlik, yemekhane, yatakhane gibi yerlerde 1sı, 1şık ve havalandırmanın sağlık şartlarına uygun olması, öğrencilerin kılıkkıyafetlerinin sağlıklı ve düzenli olması için gerekli önlemler alınır.

Ortaöğretim Kurumlarında yönetici ve öğretmenlerce (Ortaöğretim Kurumları Ödül ve Disiplin Yönetmeliği, m.6);

a) Aile içinde ve dışında şiddete maruz kalan, ilgisizlik nedeniyle veya zorlanarak Kanun ve toplumun etik kurallarına aykırı olan yollara yönelme ihtimali bulunan öğrencilerle ilgili gerekli önlemlerin alınır.

b) Öğrencilerin, diğer öğrenciler tarafından fiziksel ve ruhsal yönden zarar görmemeleri için dedikoduya, zorbalığa, tehdide, sataşmaya ve onur kırıcı her türlü lakap takılmasına karşı korunması konularında veli veya ailelerle de iş birliği yapılarak gerekli tedbirler alınır.

Öğrenci sağlığı ve güvenliği, kuşkusuz çok önemlidir; çünkü öğrenci güvenliği ve sağlığı eğitim hakkının kullanılması için olmazsa olmazdır. 
Diğer konularda başarılı uygulamalar, eğer bu iki şart sağlanırsa mümkündür. Yukarıdaki hükümler göz önüne alındığında okullarda sağlık ve güvenliğin esas olduğu, bu konudaki tedbirlerin okul yönetimlerine ve öğretmenlere bırakıldığı açıkça belirtilmektedir. Ancak son yıllarda ilk ve ortaöğretim kurumlarında artan şiddet olayları göz önüne alındığında (http://www.kesk.org.tr/node/159; Barak, 2011), mevcut hükümlerin okul yönetimlerini, kurumlarındaki güvenlik sorunlarını çözme konusunda yetkilendirmede yetersiz kaldığ söylenebilir. $\mathrm{Bu}$ nedenle, okul yönetimlerinin yetersiz kaldığı noktalarda sorunların çözümüne yönelik olarak, öğrenci sağlı̆̆ını ve güvenliğini tehdit eden ya da zarara uğratan kişilere karşı okulu daha yetkili kılan düzenlemeler yapılmalıdır.

\section{Öğrencinin Yöneltilmesi ve Rehberlik}

Milli Eğitim Temel Kanunu'nun getirdiği en önemli ilkelerden biri de öğrencilerin yöneltilmesi ilkesidir. Temel eğitimden ortaöğretime geçişte yöneltme ve yerleştirme asıl olmalıdır. Yöneltmede öğrencilerin yeteneklerinin, ilgilerinin, becerilerinin, başarıları ile birlikte göz önünde tutulması firsat eşitliği ilkesine de uygun olacaktır (Başaran, 2000, 175).

Milli Eğitim Temel Kanunu'na göre, yöneltme ilköğretimde başlar; yanılmaları önlemek ve muhtemel gelişmelere göre yeniden yöneltmeyi sağlamak için ortaöğretimde de devam eder (m.30). Okulöncesi, ilköğretim ve ortaöğretim öğrencilerinin yöneltilmesine ilişkin esaslar İlköğretim Kurumları Yönetmeliği, Ortaöğretim Kurumları Ödül ve Disiplin Yönetmeliği ile Milli Eğitim Bakanlığı Rehberlik ve Psikolojik Danışma Hizmetleri Yönetmeliği’nde ayrıntılı bir biçimde düzenlenmiştir.

Okul öncesi eğitim ve ilköğretimde hizmetler genel olarak; öğrencinin kendisi, öğretmeni/öğretmenleri ve ailesi tarafından yetenek, beceri ve diğer özelliklerinin fark edilmesine, öğrencinin yetiştiği ortamın iyileştirilmesine, bireysel ve sosyal gelişimlerinin desteklenmesine, etkili öğrenme ve çalışma becerileri ile motivasyonlarının artırılmasına, ilköğretim sonrası eğitime ve ortaöğretime devam edemeyecekler için mesleğe yönlendirmeye yöneliktir (Milli Eğitim Bakanlığı Rehberlik ve Psikolojik Danışma Hizmetleri Yönetmeliği, m.12).

İlköğretimde öğrencilerin ilgi, istek ve yeteneklerine göre yetişmeleri sağlanır. Herkesin başarılı ve mutlu olabileceği bir programa girmesi amaçlanır, bu yönde olanaklar araştırılır ve kişi desteklenir. Yöneltme, ana sınıfından başlayarak öğrenci hakkında öğrenimi boyunca yapılacak sürekli gözlem ve değerlendirmelere göre yapılır. Yöneltme, zorlayıcı değil, kişinin kararının doğru ve gerçekçi olması yönünde yol göstericidir (İlköğretimde Yöneltme Yönergesi, m.4-5) 
Orta öğretimde ise hizmetler genelde; üst öğrenime, meslek alanlarına ve mesleğe yönelmede, etkili öğrenme ve çalışma becerileri geliştirmede, meslekler ve gerektirdiği özellikler ile meslek ve çalışma yaşamı konusunda bilinçlendirmede, bireysel özelliklerini değerlendirip farkındalık düzeyini geliştirmede, bireysel ve sosyal gelişimin sürdürülüp yetişkin yaşamına hazırlanmada yoğunlaşır (Milli Eğitim Bakanlığı Rehberlik ve Psikolojik Danışma Hizmetleri Yönetmeliği, m.12).

Öğrencilerin yöneltilmesi ve rehberlik hizmetleri ile ilgili düzenlemeler, öğrencilerin bireysel ve toplumsal ihtiyaçları doğrultusunda yönelmesine yardımcı olmayı, kendisini tanımasına, bir mesleğe yönlendirilmesine ve geleceği ile ilgili karar vermesine yardımcı olmayı amaçlamaktadır. $\mathrm{Bu}$ yönüyle ilgili mevzuatın öğrenci ihtiyaçlarını gözetme ve gerekli esasları düzenlemede yeterli olduğu söylenebilir.

\section{Öğrencinin Sosyal Etkinliklere Katılımı}

Sosyal etkinlikler, eğitim programının önemli bir parçasıdır. Bu etkinlikler, öğrencilerin eğitimine büyük katkıda bulunmakta, birçok ruhsal gelişimlerini karşılayabilmektedir. Sosyal etkinlikler, öğrencilerin kendilerini yönetme alışkanlıkları kazanarak demokratik yaşama hazırlanmalarına yardımcı olmaktadır. Sosyal etkinlikler yoluyla öğrenciler, kültürel değerleri benimsemenin yanında, yeni değerler geliştirme olanağ bulmaktadır (Başaran, 2006, 339).

İlköğretim ve Ortaöğretim kurumlarında, ders dışı etkinlikler, 13.01. 2005 tarihinde yürürlüğe girmiş olan "Milli Eğitim Bakanllğ 1 İlköğretim ve Ortaöğretim Kurumları Sosyal Etkinlikler Yönetmeliği" ile düzenlenmiştir. $\mathrm{Bu}$ yönetmeliğe göre sosyal etkinliklerin amac1, ilk ve ortaöğretim kurumlarında öğrencide güven ve sorumluluk duygusu geliştirmeye, yeni ilgi alanları oluşturmaya ve beceriler kazandırmaya yönelik bilimsel, soysal, kültürel, sanatsal ve sportif alanlarda öğrenci kulübü ile toplum hizmeti çalışmalarını kapsamaktadır (m.1). Sosyal etkinlikler kapsamında öğrencinin aşağıdaki faaliyetlere da aktif katılımı ve öğrencilerce planlanması öngörülmüştür (m.20): a) Geziler, b) Yarışmalar, c) Beden eğitimi, izcilik, müzik ve halk oyunları çalışmaları, d) Yayınlar, e) Gösteriler, f) Tiyatro çalışmaları, g) Defile, sergi ve kermes.

Sosyal etkinlikler kapsamındaki faaliyetler özellikle içine kapanık, sosyal ilişkileri zayıf, kendisini ifade etmekte zorlanan öğrenciler için eğitim kurumları içerisinde sunulan önemli öğrenme ve gelişme olanaklarıdır. Anılan yönetmelik, öğrencilerin kültürel değerleri kazanması, ruhsal gelişimlerine katkı sağlamayı amaçlaması ve en önemlisi onları hayata hazırlaması bakımından önemli ve yerinde düzenlemeler getirmektedir. 


\section{SONUC}

$\mathrm{Bu}$ çalıșmada öğrencilerin hak ve sorumlulukları başta anayasa, ilgili yasalar, uluslararası antlaşmalar ve ağırlıklı olarak Milli Eğitim Bakanlı̆̆g'nın yasal düzenlemeleri çerçevesinde incelenmiştir.

$\mathrm{Bu}$ incelemeler sirasında, öğrencilerle ilgili olarak İlköğretim Kurumları, Ortaöğretim Kurumları vb. yönetmeliklerde çeşitli konulara iliş̧in öğrenci hak ve sorumluluklarını içeren açıklamalara ulaşılmıştır. Yönetmeliklerde gözlenen en önemli eksiklik, öğrenci hak ve sorumluluklarının örneğin, İlköğretim Kurumları Yönetmeliği’nde ya da Ortaöğretim Kurumları Yönetmeliği'nde ilgili bir başlık altında düzenlenmemiş olmasıdır. Oysa okulun varlık sebebi ögrencidir. Okulun en önemli girdisi olan öğrencilerin hak ve sorumluluklarının öğrenci ve tüm eğitim personeli tarafindan çok iyi bilinmesi gerekmektedir. Var olan düzenlemelerden bunlara ulaşmak mümkün olsa da ilköğretim ve ortaöğretimle ilgili yasal düzenlemelerde, öğrenci hak ve sorumluluklarının sistemli bir biçimde ele alınmaması veya dağınıklığı önemli eksikliktir. İlköğretim Kurumları Yönetmeliği'nde öğrencilerden beklenen davranışlar bir bütün halinde belirtilmiştir ancak hakların benzer şekilde sıralandığı bir bütüne rastlanmamıştır. Örneğin Amerika Birleşik Devletleri’nde öğrencilere sahip oldukları hak ve sorumluluklar açıklanmakta ve bu haklar güvence altına alınmaktadır. Türkiye'de de derli toplu bilgiyi bir arada sunma bakımından benzer bir uygulamanın yapılmasının, diğer bir deyişle hem ilköğretim hem de ortaöğretim öğrencileri ve velileri için hak ve sorumluluklarının bildirildiği yönetmelik veya yönergeler kapsamında hazırlanmasının yararlı olacağı düşünülmektedir.

Türkiye'de öğrenciler ile ilgili yasal düzenlemelerin iyileştirilmesi için genel olarak önerilebilir: 1) İlgili mevzuata, temel eğitim süresinin, dünyadaki çağdaş eğilimlere paralel olarak gerekli alt yapı hazırlandıktan sonra sekiz yıldan 12 yıla çıkarılmasına ilişkin bir hüküm konmalıdır. 2) İlköğretim kurumlarındaki öğrenci devamsızlığına ilişkin maddeler bulanıklığ 1 giderecek ve keyfiyete son verecek biçimde bir ölçüt getirilerek yeniden düzenlenmelidir. 3) Disiplin konusu, yalnızca kurallardan olumsuz yönde sapan öğrencileri cezalandırmak için değil, aynı zamanda olumlu davranışı pekiştirmek için kullanılan bir mekanizma olarak düzenlenmelidir. 4) "Ortaöğretim Kurumları Ödül ve Disiplin Yönetmeliği” nde, disiplinin ceza ile eş anlamlı kullanılması yanlışına son verilerek, "Ödül ve Ceza" ya da sadece "Disiplin Yönetmeliği" olarak anılmalıdır. 


\section{KAYNAKLAR}

Ataünal, A. (2003). Niçin ve Nasıl Bir Öğretmen? Ankara: Milli Eğitim Vakfi Yayınları. No.4.

Balcı, A. (2005). Eğitim Terimleri Sözlüğ̈̈̈. Ankara: Tekağaç Kitap Basım, Yayım, Dağıtım Ltd. Şti.

Barak, B. (2011, 1 Haziran). Okullarda şiddet arttı. Yeni Güney Gazetesi. [Online]:http://www.yeniguney.net/haber/okullarda-siddet-artti adresinden 6 Ağustos 2011 tarihinde indirilmiştir.

Başaran, İ. E. (2000). Eğitim Yönetimi. Ankara: Feryal Matbaası.

Başaran, İ. E. (2006). Türk Eğitim Sistemi ve Okul Yönetimi. Ankara: Ekinoks Yayıncilı.

Cerit, Y. (1996). Okul ve Öğretmenlik. M.Karslı (Ed.) Öğretmenlik Mesleğine Giriş kitabı içinde. Ankara: Pegem A Yayıncılık.

İlköğretim ve Eğitim Kanunu. (1961). T. C. Resmi Gazete, 12 Ocak, 1961.

İlköğretimde Yöneltme Yönergesi. (2003). Tebliğler Dergisi, Eylül, 2003.

Kepenekçi-Karaman, Y., 1997a. Eğitim işgörenlerinin disiplin sorunları, Ankara Üniversitesi Eğitim Bilimleri Fakültesi Dergisi, 27(2):861-874.

Kepenekçi-Karaman, Y. (2008). Eğitimciler İçin İnsan Hakları ve Vatandaşlık. Ankara: Ekinoks Yayınevi.

Kepenekçi-Karaman, Y. (2003). Hukuk ve Öğretmenlik Mesleği. M. Karslı (Ed.) Öğretmenlik Mesleğine Giriş kitabı içinde. Ankara: Pegem A Yayıncilik.

Millî Eğitim Bakanlığı İlköğretim Kurumları Yönetmeliği. (2003). T. C. Resmi Gazete, 27 Ağustos, 2003.

Millî Eğitim Bakanlığ1 Ortaöğretim Kurumları Yönetmeliği. (2003). T. C. Resmi Gazete, 31 Temmuz, 2009.

Milli Eğitim Bakanlığı Rehberlik ve Psikolojik Danışma Hizmetleri Yönetmeliği. (2001). Resmi Gazete, 17 Nisan 2001.

Nartgün, Z. (2003). Ölçme Değerlendirme ve Öğretmenlik Mesleği. Mehmet Durdu Karslı (Ed.) Öğretmenlik Mesleğine Giriş kitabı içinde. Ankara: Pegem A Yayıncilık.

Taymaz, H. (2003). Okul Yönetimi. Ankara: Pegem A Yayıncılık.

Tekin, H. (1991). Eğitimde Ölçme ve Değerlendirme. Ankara: Yarg1 Matbaas1.[Online]:http://www.kesk.org.tr/node/159 adresinden 8 Ağustos 2011 tarihinde indirilmiştir. 